\title{
CULTURAL VALUES AND NORMS OF COMMUNICATION: A VIEW FROM THE MIDDLE EAST
}

\author{
Neda Kameh Khosh ${ }^{1 *}$, Amr A. A. Khalil ${ }^{2}$, Hashem Hani Shehadeh Alhaded $^{3}$ \\ ${ }^{1}$ People's Friendship University of Russia, Russian Federation, kamekh_khosh_n@pfur.ru \\ ${ }^{2}$ People's Friendship University of Russia, Russian Federation, windfall.roc13@hotmail.com \\ ${ }^{3}$ People's Friendship University of Russia, Russian Federation, hashem_1256@hotmail.com \\ ${ }^{*}$ Corresponding Author
}

\begin{abstract}
Cultural knowledge is an important component of intercultural communicative competence which is fundamental for the second language acquisition. It is essential for the development of sociocultural, pragmatic, and communicative competences of second language learners. Cultural values of any community pilot how people interact with one another. To put it differently, they form understanding of politeness which being a universal phenomenon differs across cultures and shape communicative styles. The present study analyzes three Middle Eastern cultures (Persian, Syrian and Jordanian) and seeks to demonstrate how Muslim values and notions of politeness construct the norms of interpersonal interactions. The paper is limited to the speech act of address in the settings of family, acquaintances and strangers. The data for the study were collected from two questionnaires, serial television drama, YouTube social experiments as well as ethnographic observations. They were examined drawing on (im)politeness theory, speech act theory, discourse analysis, research on identity construction and cultural studies. The paper highlights some communicative specificities of the three Middle Eastern lingua-cultures concerning address forms and their usage and shows how they are predetermined by culture and cultural values. Our findings confirm the fact that communicative styles in collectivistic Muslim cultures are status-oriented, the individuals of these cultures demonstrate a remarkable vertical distance and highly regard status and age. Our results manifest that the principals of identity primarily emerging from Muslims' holy book "Quran" are the basis of politeness norms in Persian, Syrian and Jordanian communicative cultures and indicate that linguistic politeness in these cultural contexts are strongly established on showing respect in addressing older people. The findings of the research may help foster intercultural communications if employed in second language teaching classes and may have significant implications in translation studies and practice.
\end{abstract}

Keywords: Politeness, impoliteness, cultural values, communicative styles, norms of communication, Muslim values.

\section{Acknowledgement}

The publication has been prepared with the support of the "RUDN University Program 5-100".

\section{INTRODUCTION}

Addressing one another is an essential aspect of daily communication as it plays a key role in social relationship makings, encodes attitudes and casts light on relationships of interlocutors. Address systems reflect acts and cultural values of interlocutors. Moreover, forms of address symbolize channels of politeness 
through which collocutors' identity and conceptualization of their relationships with others are expressed. Since politeness concepts and notions are not communicated the same way across different cultures (Abugharsa 2014), address behavior varies in different cultures. In other words, what seems to be polite in our culture may not seem so in other cultures (Hamza 2007). In this sense, choosing appropriate forms of address entails acquiring both socio-pragmatic competence, defined as the knowledge of variables such as social power and social distance (DuFon 2010, 309) and pragma-linguistic competence, defined as the speaker's knowledge of the linguistic resources and their pragmatic meanings as well (Hassal 2008, 73).

Correspondingly, Khalil, Larina \& Suryanarayan (2018) point out that it is very important for SL learners to acquire a socio-pragmatic, pragma-linguistic and sociocultural competence, and be conscious of values, social organization and attitudes of the target culture's people in order to master the use of address forms. Acquiring the aforementioned competencies is problematic and challenging to not only the SL learner but also the native speaker due to the complexity of address systems (DuFon 2010).

The present paper attempts to shed light on showing respect to older people through the speech act of address forms in Iran, Syria and Jordan. The paper also sets out to illustrate how cultural values and notions of politeness in Muslim cultures construct the norms of interpersonal communication. We, herein, limit ourselves to showing respect through forms of address use in the settings of family, acquaintances and strangers. First, we will discuss some theoretical issues concerning politeness, cultural values and the impact of cultural values on politeness as well as communicative behaviors, addressing forms and the influence of some influential fractures such age, gender and religion in order to apply an appropriate terms of address in Muslim cultures of Iran, Syria and Jordon. Further, we will present the results of our research concentrated on displaying respect by using addressing forms towards older people in the settings of family, acquaintances and strangers in Muslim cultures of Iran, Syria and Jordan.

\section{POLITENESS, CULTURAL VALUES AND ADDRESS FORMS}

In numerous studies, it has been disclosed that politeness is a concept, constructed on the base of culture [Watts 2003, p. 70, Haugh \& Chang, 2019, Locher \& Larina, 2019, Tzanne \& Sifianou, 2019]. In contrary to universal nature of politeness, there are different understandings and norms of politeness among cultures. Indeed, it has its cultural particularity in different cultures. From an intercultural perspective of politeness, as politeness has different understandings and norms among cultures, the identical verbal or non-verbal act of behaving politely in one culture may be conceived as an inappropriate or even completely impolite in another culture. (Blum-Kulka and House 1989, Brown \& Levinson, 1978 \& 1987, Leech, 2014, Leech \& Larina, 2014, Larina, 2008, 2009, 2015, Sifianou, 1992)

According to Watts $(2003,14)$, even the lexemes of polite and politeness may differ in meaning and their connected connotations in different cultures. Meanwhile, he believes that people's perception of politeness and polite behavior vary among individuals as well as situations. He strongly emphasizes that politeness is an evaluation process applied in a subjective approach (Watts, 2003). In order to act politely in another culture, people should possess skills in applying culture-specific strategies, which might vary from the same strategies in their own culture. Consequently, people have to modify their verbal and non-verbal behavior. Wierzbicka $(1985,145)$ believes that linguistic distinctions are shaped due to cultural aspects that are much more influential than mere politeness norms and are connected with cultural distinctions. The comprehending of cultural differences which affect communicative behavior is considered as an essential component of intercultural communicative competence (Wierzbicka, 1985). However, politeness is tightly associated with the most fundamental principles of interpersonal relationships and sociocultural organization within social categories and should be taken into consideration in the context of social distance as well as power distance which are viewed as the main criteria in culture (Hofstede, 1991). It has been also debated that social structure of society and cultural values influence on understanding of politeness and pilot the process of selecting politeness strategies in order to perform a specific speech act. These viewpoints correlate relatively to the politeness definition presented by Sifianou as "the set of social values which instructs interactants to consider each other by satisfying shared expectations" (Sifianou 1992, 86).

Youssef (2012: 146) points out that studying politeness entails understanding cultural values and social norms of a specific speech community. In other words, social values, customs and awareness are highly incorporated in politeness notions with which individuals make use of language (Wardhaugh \& Fuller, 2015). In Muslim cultures, age is a very significant social factor i.e., the older people are, the more respect they get. The value of age is clear in one of the hadeeths of Prophet Muhammad (PBUH) when he said those who have no mercy on our young people and do not respect the elderly, they do not belong to our group (society) (Cf. Khalil \& Larina, 2018). Muslims are encouraged to be kind to other people, which is presented in the hadeeths of Prophet Muhammad (PBUH) and holy Quran as well. For instance, the Prophet Muhammad 
(PBUH) said that in their mutual sympathy, compassion and kindness, the believers are like one body that responds to with fever and wakefulness when a limb suffers (Nawawi, 2014). Islam regards taking care of one's parents and older people as an honor and blessing. It is one of the Islamic rules that older people should be taken care of mercifully with selflessness and kindness.

Meanwhile, language is well known for being a speaker-addressee relationship sensitive case in which sensitivity is significantly manifested in the use of address forms in daily interactions. Forms of address, as seen by Oyetade (1995), are expressions or words, employed by the speaker in interactive, dyadic and faceto-face encounters in order to characterize the addressee. Keshavarz (2001) defines forms of address as linguistic items, utilized by the speaker to refer to or draw the addressee's attention. According to Braun (1988: 7), terms of address are strong deictic components as they designate the interlocutors. It is plausible to mention that our paper follows all the above-mentioned definitions.

The main concern of the study of address forms, generally, is how interlocutors use the repertoire of address variants available to them and the information exhibited by the choice of these variants about social organization and hierarchy (Braun 1988) (Brown and Gilman 1960). To be more specific, forms of address are "socially driven phenomena" because they reflect the individuals' social relation complexities in a given speech community (Peoples and Bailey 2010). As stated by Wierzbicka (2016), the lexical semantics of kinship terms is significant for cultural anthropology as their meanings accurately highlight how collocutors of a particular language ideate their social relationships. Therefore, forms of address can be examined in the framework of (im)politeness theories as the choice of a specific address term is determined by how polite/impolite it sounds in a specific situation. Brown and Levinson (1978), for example, regard forms of address as significant linguistic mechanisms that mark the interlocutors' evaluation of their relationships and attitudes towards others in daily communicative events.

They, also, bring to discussion the notion that the use of appropriate address forms allows the speaker to position himself/herself as one of a specific social group. On the other hand, an inappropriate choice of address forms may cause a good interaction to cease. It is worthwhile mentioning that the significance of address variants exists in their role and function as markers of social distance as well as social status which reveal the speakers' emotions to the addressee and act as means of saving one's face (Brown and Levinson 1978). Furthermore, forms of address are employed by the speaker to show respect to the addressee's face (ibid).

In a similar vein, Braun (1988: 110) argues that interlocutors, choosing between polite and less polite forms of address and get polite forms of address enjoy a superior position (higher status) over other interlocutors in politeness hierarchy.

In the light of the above-mentioned discussion, one can understand the interrelationship between forms of address and politeness, i.e., politeness concepts and notions can be recognized through the prism of address behavior and its rules in a given speech community (e.g. Kotorova, 2018, Rhee, 2019, Wierzbicka, 2016 \& 2020). For instance, Khalil \& Larina (2018) point out that the use of Arabic kinship terms of address, depending on age and gender factors, to address older strangers shows the "we" orientation (Larina \& Ozyumenko, 2016, Larina, et al. 2017) and large power distance of Arabs, i.e., it shows respect and closeness.

Based on our data, the frequency of applying honorific and respectful forms of address in Muslim cultures such as the Arab and Persian cultures disclose the importance and significance of courtesy in these cultures. It seems that being courteous and humble through interpersonal interaction is an outstanding attribute of the Muslims addressing system. Besides, it appears that Muslim utterers such as the Arab and Persian ones are very attentive to their face work. Another significant specificity of Muslim cultures is manifested in the application of kinship terms. Muslims in Arab countries and Iran are perfectly dependent on family relations and this feature is specifically noticeable in the use of reverse forms of address or kinship terms for both relatives and non-relatives. From one hand, limitations in using of personal names and pronominal, and on the other hand, the absolute tendency to apply general, occupational and respectful titles as well as formal terms, put emphasis on this fact that the sense of formality is also another specific attribute of these cultures and their applied languages in general meaning and forms of address in particular meaning. To address one another, Arabs and Persian interlocutors make use of distinctive techniques. This wide diversity provides these Muslim utterers with a broad range of terms and forms in order to address addresses. The process of selecting an appropriate forms of address is proceeded directly under the impression of different major factors such as age, gender, social status, religion, family ties, degree of respect, degree of familiarity as well as degree of intimacy among interlocutors (AbuAmsha 2010, Aghagolzadeh \& Asadpour 2011, Aliakbari \& Toni 2008, Keshavarz 1988, Kamehkhosh \& Larina, 2020, Saberi 2012, Sharifi Moghadam, Yazdanpanah, 
\& Abolhassanizadeh 2013). In our present study, we put a special emphasis on the impact of culture and cultural values on forms of address in three Middle Eastern cultures of Iran, Syria and Jordan.

\section{DATA AND METHODOLOGY}

The present study makes use of quantitative research methods. Our data were elicited from primary sources through two questionnaires, television drama, social media experiments and ethnographic observations.

We have focused on showing respect to older people through the prism of address forms in Iran, Syria and Jordan, mainly, in the settings of family, acquaintances and strangers. We, herein, attempt to account for some communicative specificities of the three Middle Eastern cultures regarding address forms and to what extent the choice of these forms is predetermined by culture and cultural values. To shed light on how and why people of Iran, Syria and Jordan choose from the repertoire of address available in their languages to show respect to older collocutors, the revealed differences and similarities have been elucidated drawing on (im)politeness theory, speech act theory, discourse analysis, research on identity construction and cultural studies.

\section{RESULTS AND DISCUSSIONS}

\subsection{Family Setting}

Kinship terms, widely circulated in Muslim cultures, are used to designate the different relations among family members, such as brother - sister, mother - son, uncle - niece, father - daughter, etc. Muslim families are hieratical entities in which older family members occupy a higher status than the younger ones. Therefore, it would sound very odd if a younger person calls his/her father, mother, uncle, aunt, etc. using their first names. This practice is deeply rooted in the Islamic history. For instance, the prophet Muhammad (PBUH) said that sons and daughters should not call their parents by their first names (Cf. Khalil \& Larina 2018).

Based on our data collected from the Persian culture, the styles of communication in addressing in bottomup context between children to parents are formed only in one type of addressing by "Mom / Dad" as in the situations below when the son addresses his mother in order to bring him a glass of water (1), when the son addresses his father for repairing his bike (2) and when the father asks his daughter the salt at dinner table and the daughter gives it to him (3).

(1) Son: Maman (Mom), would you mind please doing me a favor and bringing me a glass of water?

$$
\text { مامان، اكه زحمتى نبيت لطفا محبت مى كنيد و براى من يكى ليوان آب ميارين? }
$$

(2) Son: Baba (Dad), could you please do a favor to me and repair my bike?

$$
\text { بابا، ميتونيد لطفا محبت كنيد و دوجرخه ام رو تعدير كنيد؟ }
$$

(3) Daughter: Baba (Dad), here you are.

$$
\text { بابا، ندكدون خدمت شما. }
$$

In the family setting, hierarchy is very important. Nephews and nieces in Syria, for example, are not expected to address their uncles and aunts by their first names. Senior kinship terms, therefore, are used to show respect to older relatives, e.g., Ammo or Ammi 'my paternal uncle', Amto or Amti 'my paternal aunt' as the older relatives enjoy a higher rank than the younger ones, especially when the addressee's age is approximately the same as the speaker's parents.

Example (4) taken from Syrian Arabic includes a 5-year-old child asking his maternal aunt who is around 28 years old to make him a sandwich and example (5) shows the same child thanking his maternal aunt as she gives him what he needs. In both examples, the kinship term, maternal aunt, was used by the child to show respect.

(4) Child: Khalto, (maternal aunt), make me a sandwich.

$$
\text { الطفل: خالتو، اعطبلي سندوبشة. }
$$

(5) Child: Thank you, Khalto (maternal aunt).

$$
\text { الطفل: شكراً، خالتو. }
$$

Similarly, People in Jordan are also expected to address their older relatives by a suitable kinship term. An interesting observation confirms the large power distance in Jordan when a teenager politely addresses his father's cousin (17 years older). Examples (6) and (7) show the teenager addressing his father's cousin as 
paternal uncle because age has a great value in not only the Jordanian but also Persian and Syrian cultures.

(6) Teenager: It has been a long time since we saw you, Ammo (my paternal uncle).

المراهق: وين عنك عمو، زمان ما شفناك

(7) Teenager: Come in please, Ammo (my paternal uncle).

\subsection{Acquaintances}

The use of Kinship terms is stretched in Iran, Syria and Jordan to enrich and maintain the social interaction among non-relatives, i.e., kinship terms can be used to address both acquaintances and strangers as well. Our data show that in all three cultures, using kinship terms is fundamental to demonstrate respect and closeness to older people who do not belong to the family circle such as acquaintances, i.e., the cultures of Iran, Syria and Jordan are we-identity cultures in which closeness and intimacy shape the communicative style.

Persian forms of address, such as Ameh 'paternal aunt' and Khale 'maternal aunt' are used to address older female acquaintances and Amoo 'paternal uncle' and Dayi 'maternal uncle' are used to address older male acquaintances, as in the situations below, when a girl asks her friend's mother to come to her house (6), and when a boy asks his father's friend to pick him up from school (7). Furthermore, Amoo 'paternal uncle' and Khale 'maternal aunt' are also used to address other older male and female acquaintances for instance mother's friend and neighbors, as in the situations below, when the girl asks her mother's friend about her family (8) and when the son ask his neighbor to call his boy to play with in the yard (9).

(6) Girl: Ameh, (paternal aunt) when you come to our house? I miss you a lot.

$$
\text { عده، كى مياى خوندون? دلم برات خيلى تنكى شده. }
$$

(7) Boy: Amoo, (paternal uncle) would you please do a favor to me and pick me up from school today?

$$
\text { عمو، ميشه لطفا امروز بهم لطف كنى و بياى مدرسه دنبالم؟ }
$$

(8) Girl: Khale, (maternal aunt) how are you? How are things with your children?

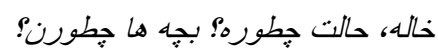

(9) Boy: Amoo, (paternal uncle) would you mind please calling Ali to play together in yard?

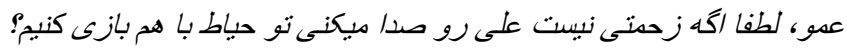

According to our data, forms of address, such as Amto, Amti or Tant 'my paternal aunt/paternal aunt'; and Khalti or Khalto 'maternal aunt/my maternal aunt' can be used to address older female acquaintances. In addition, Ammi or Ammo 'paternal uncle/my paternal uncle'; and Khali or Khalo 'maternal uncle/my maternal uncle' are used to address older male acquaintances such as parents' friends and older neighbors. An example taken from our Syrian Arabic data includes a conversation between a 22-year-old girl referred to herein as "girl" and her friend's mother referred to as "older woman". In example (10), the older woman addresses the younger girl using the first name, while example (11) shows the younger girl choosing a senior kinship term as a form of address to show respect:

(10) Older woman: How are you, Razan?

$$
\text { المراة الأكبر سناً: كيفك رزان؟ }
$$

(11) Girl: Hello, Khalti (maternal aunt). I am fine, praise be to Allah.

$$
\text { الفتاة: أهلًً، خالتي، بخير الحمد شه. }
$$

Moving to the Jordanian culture, our findings exhibit that respecting older acquaintances through the prism of address forms is not different from the Persian and Syrian cultures. Amto, Amti or Ammah 'my paternal aunt/paternal aunt'; and Khalah or Khalto 'maternal aunt/my maternal aunt' to address older female acquaintances. Furthermore, Am, Ammi or Ammo 'paternal uncle/my paternal uncle'; and Khal, Khali or Khalo 'maternal uncle/my maternal uncle' are utilized to address older male acquaintances. A 28-year-old man in Jordan in example (12) addresses his 50-year-old male neighbor by a senior kinship term while the older neighbor in example (13) addresses the young man by his first name:

(12) Younger neighbor: Peace be upon you, Ammo (paternal uncle) Abu Ahmad. 
(13) Older neighbor: Peace be upon you, Hashem.

$$
\text { الجار الأكبر سناً: وعليكم والسلام ورحمة الله وبركاته، هاثم. }
$$

\subsection{Strangers}

Our findings show that the three Middle Eastern cultures (Persian, Syrian and Jordanian) extend the use of kin-type address forms to address strangers to show respect that entails closeness as well. However, the use of kinship terms to address older strangers is not completely identical in the cultures of Iran, Jordan and Syria. In Syria and Jordan, for example, the same kinship terms used to address acquaintances, i.e., Ammto or Ammti 'my paternal aunt'; and Khalti or Khalto 'my maternal aunt' are used to address older female strangers while Ammi or Ammo 'my paternal uncle'; and Khali or Khalo 'my maternal uncle' are used to address older male strangers. In Iran, on the other hand, Maman 'mother' and Baba 'father' could be used to address female and male strangers, respectively. It is important to note that using Maman 'mother' and Baba 'father' to address strangers is not frequent. The data collected from the Persian culture show that forms of address such as 'Agha / Mr.' for male strangers and 'Khanoom / Mrs.' for female strangers are used frequently in order to pay respect and honor to older strangers, as in the situations below when a young man asks an old woman about an address in a new district (14), and when a young girl politely asks an older man to move his car from her way (15).

(14) Young man: Khanoom (Mrs), would you please tell me, where this address is?

$$
\text { خانم، ميشه لطفا به من بكين ابن آدرس كجاست؟ }
$$

(15) Girl: Agha (Mr.) would you mind please moving your car? It is on my way.

$$
\text { آقا ميشه لطفا ماشينتونو جا به جا كنيب؟ سر راه منه. }
$$

As argued above, kinship terms are used to address older strangers in Syria. Examples (16) and (17) show a young man, who wants to buy a flat, decides to ask an old man (60 years old approximately) about the neighborhood. To do so, the young man addresses the older one by a senior kinship term, paternal uncle:

(16) Young man: Good afternoon, Ammi (paternal uncle).

$$
\text { الشاب: مسا الخير، عمي. }
$$

(17) Young man: How is this neighborhood? I mean, Ammi (paternal uncle), is it quiet?

$$
\text { الشاب: شو رأيك بهالحارة؛ بيني، عمي، هادية؟ }
$$

Examples (18) and (19) are typical examples of respecting older strangers in Jordan. The examples are part from a social media experiment when an interviewer asks older people on the street a few questions. The interviewer addresses an older woman and her husband using senior kinship terms, maternal aunt and paternal uncle, respectively.

(18) Interviewer: Hello, Khalah (maternal aunt). How are you doing?

(19) Interviewer: How are you, Am (paternal uncle)?

$$
\text { المذيع: مرحبا، خالة. كيف حالك؟ }
$$

$$
\text { المذيع: كيفك، عم? }
$$

Our analysis of address forms showing respect to older people reveals an almost identical address behavior in Iran, Syria and Jordan. The Persian, Syrian and Jordanian people highly regard hierarchy within the family and society as their cultures are characterized by a large power distance, that is, calling older acquaintances by their first names, for instance, could be seen as a violation of the cultural norm. The communicative style in Iran, Syria and Jordan is greatly influenced by the Muslim values that indicate the importance of the elderly.

\section{CONCLUSIONS}

The present study aimed to examine how Muslim cultural values and politeness notions in Iran, Syria and Jordan construct the communicative styles in daily encounters. Our study offers an attempt to illustrate the speech act of address concerning showing respect to older people in the settings of family, acquaintances and strangers.

Our findings indicate that Persian, Syrian and Jordanian form of address demonstrate culture specific peculiarities, predetermined by cultural values implanted in the use of kin-type forms of address. The 
extended use of kinship terms to include those who do not belong to the speaker's family confirms the fact that the Persian, Syrian and Jordanian cultures are we-cultures (Larina et al. 2017) in which being polite entails showing closeness and respect to older people. In other words, this form of behavioral tendency in respecting elders in Muslim cultures emerges from religion, traditions and beliefs based on which younger people respect the elders due to their worthwhile experiences, so that they could extract and apply their wise and intelligent knowledge in their life.

It is worthwhile noting that our findings point out the communicative styles of the studied cultures are characterized by status orientation as well as intimacy. Linguistic forms and cultural values in addition to the careful choice of address forms interweave exceptionally to show the importance of hierarchy, bestowed by age in Muslim cultures of Iran, Syria and Jordan.

It is important to note that our study shall not be deemed as complete due to its limited nature. It provides a general overview of some address forms showing respect to older people. Acquiring intercultural communicative competence is crucial for the development of sociocultural, pragmatic, and communicative competences of second language learners. Once they are aware of cultural differences, second language learners could find explanations of different aspects of the target language use.

\section{REFERENCE LIST}

AbuAmsha, D. I. (2010). Terms of address in Palestinian Arabic. Indiana, USA: Ball State University.

Abugharsa, A. (2014). Terms of address in Libyan Arabic compared to other Arabic varieties.

Aghagolzadeh, F., \& Asadpour, H. (2011). A critical discourse analysis on terms of address in Persian. Intl. J. Humanities, Volume 18(1), 135-160.

Aliakbari, M., \& Toni, A. (2008). The realization of address terms in modern Persian in Iran: A sociolinguistic study. Linguistic online 35, 3/08, 3-12.

Blum-Kulka, S., \& House, J. (1989). Cross-cultural pragmatics: Requests and apologies. In S. Blum-Kulka, J. House, \& G. Kasper (Eds.), Cross-Cultural and Situational Variation in Requesting Behaviour (pp. 123-154). Norwood, NJ: Ablex.

Braun , F. (1988). Terms of address: Problems of patterns and usage in various languages and cultures. Journal of Linguistics, Volume 26, Issue 1.

Brown, P., \& Levinson, S. (1978). Universals in language usage: Politeness phenomenon. In E. N. Goody (Ed.), Questions and Politeness: Strategies in Social Interaction (pp. 56-311). Cambridge, UK: Cambridge University Press.

Brown, P., \& Levinson, S. C. (1978 \& 1987). Politeness: Some Universals in Language Usage. (J. J. Gumperz, Ed.) New York, USA: Cambridge University Press: Press Syndicate of the University Of Cambridge.

Brown, R., \& Gilman, A. (1960). The pronouns of power and solidarity. In T. A. Sebeok (Ed.), Language and Social Structures: Style in Language (pp. 253-276). MIT Press.

DuFon, M. A. (2010). The acquisition of terms of address. In A. Trosborg (Ed.), Pragmatics across Languages and Cultures (pp. 300-323). Berlin, Germany: Walter de Gruyter Mouton.

Hamza, A. A. (2007). Cross-cultural linguistic politeness: Misunderstanding between Arabs and British speakers of English. School of Development and Society, Department of English. London, UK: Sheffield Hallam University.

Hassal, T. (2008). Pragmatic performanc: What are learners thinking? In E. Alcon Soler, \& A. Martinez Flor (Eds.), Investigating Pragmatics in Foreign Language Learning: Teaching and Testing (pp. 72-93).

Haugh, M., \& Chang, W.-L. M. (2019). Indexical and sequential properties of criticisms in initial interactions: Implications for examining (im)politeness across cultures. Russian Journal of Linguistics, Volume 23, No. 4, 904-929. doi:10.22363/2312-9182-2019-23-4-904-929

Hofstede, G. (1991). Cultures and Organizations: Software of the Mind. Limburgat Maastricht, The 
Netherlands: The McGraw-Hills Companies.

Kamehkhosh, N., \& Larina, T. V. (2020). Cultural values and politeness strategies in British and Persian family discourse. Proceedings of INTCESS 2020: 7th International Conference on Education and Social Sciences , 603-610.

Keshavarz , M. H. (1988). Forms of address in post-revolutionary Iranian Persian: A sociolinguistic analysis. Language in Society, Volume 17, No. 4, 565-575.

Keshavarz, M. H. (2001). The role of social context, intimacy and distance in the choice of forms of address. International Journal of the Sociology of Language, , 148. doi:10.1515/ijsl.2001.015

Khalil, A., \& Larina, T. V. (2018). Arabic of terms: Sociolinguistic overview. The Eurooean Proceedings of Social and Behavioural Sciences EpSBS, Volume XXXIX - WUT: Word, Utterance, Text: Cognitive, Pragmatic and Cultural Aspects, 299-309. doi:http://dx.doi.org/10.15405/epsbs.2018.04.02.44

Khalil, A., Larina, T. V., \& Suryanarayan, N. (2018). Sociocultural competence in understanding forms of address: Case study of kinship terms in different cultural contexts. EDULEARN 18 Proceedings: 10 th International Conference on Education and New Learning Technologies., 3038-3045. doi:10.21125/edulearn.2018.07999, ISBN: 978-84-09-02709-5, ISSN: 2340-1117

Kotorova, E. (2018). Analysis of kinship terms using natural semantic metalanguage: Anna Wierzbicka's approach. Russian Journal of Linguistics 22(4), 701-710.

Larina, T. V. (2008). Directness, imposition and politeness in English and Russian. In T. V. Larina, What Do You Mean?: The Pragmatics of Intercultural Interaction and Communicative Styles (pp. 33-38). London, UK: Cambridge ESOL Research Notes 33.

Larina, T. V. (2009). Politeness and communicative style: Comparative analysis of English and Russian language and culture traditions. Languages of Slavic Cultures.

Larina, T. V. (2015). Culture-specific communicative styles as a framework for interpreting linguistic and cultural idiosyncrasies*. BRILL: International Review of Pragmatics 7, 195-215.

Larina, T. V. (2015). Intercultural Communication: Theory and Practice. Moscow, Russia: People's Friendship University of Russia.

Larina, T. V., \& Ozyumenko, V. (2016). Ethnic identity in language and communication. Cuadernos de Rusística Española, 12, 57-68.

Larina, T. V., Kurteš, S., \& Ozyumenko, V. (2017). I-identity vs we-identity in language and discourse: AngloSlavonic perspectives. Lodz Papers in Pragmatics, Volum 13, No. 2, 109-128.

Leech, G. (2014). The Pragmatics of Politeness. (N. Coupland, \& A. Jaworski, Eds.) New York, USA: Oxford University Press.

Leech, G., \& Larina, T. V. (2014). Politeness: West and East. Russian Journal of Linguistics, No.4,, 9-34.

Locher, M. A., \& Larina, T. V. (2019). Introduction to politeness and impoliteness research in global contexts. Russian Journal of Linguistics, Volume 23, No. 4, 873-903. doi:10.22363/2312-9182-2019-23-4-873903

Nawawi, Y. (2014). Riyad as Salihin: The Gardens of the Righteous. Clifton, USA: Tughra Books.

Oyetade, S. O. (1995). A sociolinguistic analysis of address forms in Yoruba. Language in Society, 24 (04),, 515. doi:10.1017/s004740450001900x

Peoples, J., \& Bailey, G. (2010). Humanity: An introduction to cultural anthropology. MA: Engage Learning.

Rhee, S. (2019). Politeness pressure on grammar: The case of first and second person pronouns and address terms in Korean. Russian Journal of Linguistics 23 (4), 950-974. doi:10.22363/2312-91822019-23-4-950-974

Saberi, K. (2012). Routine politeness formulae in Persian: A socio-lexical analysis of greetings, leave-taking, apologizing, thanking and requesting. Doctor of Philosophy in Linguistics, University of Canterbury, Christchurch, New Zealand.

Sharifi Moghadam, A., Yazdanpanah, L., \& Abolhassanizadeh, V. (2013). The analysis of Persian address terms based on the theory of politeness. SKASE Journal of Theoretical Linguistics (online), Volume 
10, No.3 , 55-71.

Sifianou, M. (1992). Politeness phenomena in England and Greece: A cross-cultural perspective. Journal of Pragmatics 22,, 227-232.

Tzanne, A., \& Sifianou, M. (2019). Understanding of impoliteness in Greek contexts. Russian Journal of Linguistics, Volume 23, No. 4, 1014-1038. doi:10.22363/2312-9182-2019-23-4-1014-1038

Wardhaugh, R., \& Fuller, J. M. (2015). An Introduction to Sociolinguistics (7th ed.). Wiley Blackwell.

Watts, R. J. (2003). Politeness. Cambridge, UK: Cambridge University Press: Press Syndicate of the University of Cambridge.

Wierzbicka, A. (1985). Different cultures, different languages, different speech acts: Polish vs. English. ScienceDirect: Journal of Pragmatics, Volume 9, Issues 2-3, 145-178.

Wierzbicka , A. (2016). Back to "Mother" and "Father": Overcoming the Eurocentrism of kinship studies through eight lexical universals. Current Anthropology 57,, 408-428.

Wierzbicka, A. (2020). Addressing God in European languages: Different meanings, different cultural attitudes. Russian Journal of Linguistics 24(2), 259-293.

Youssef, A. M. (2012). Study of request strategies employed by Libyan and Malay postgraduate students at USM. International Journal of Learning and Development 2(2),, 144-151. 